\title{
Staff education resource regarded as the capital asset of a company
}

\author{
Lyudmila Kopteva ${ }^{1, *}$, Maria Ivanova ${ }^{2}$ and Sergey Barinov ${ }^{3}$ \\ ${ }^{1}$ Saint-Petersburg State University of Aerospase Instrumentation, 67, Bolshaya Morskaia str., 190000, \\ Saint-Petersburg, Russia \\ ${ }^{2}$ Saint-Petersburg State University of Civil Aviation, 196210, 38, Pilots str., Saint-Petersburg, Russia \\ ${ }^{3}$ Moscow State University of Civil Engineering, 26, Yaroslavskoye Shosse, 109377, Moscow, Russia
}

\begin{abstract}
Personnel training lasts a lifetime. This is what the existing system of persistent professional education is aimed at. This system implies the possibility of continuing the education at any moment of life from the level at which a person stopped previously. In the article, the concept of continuous professional training in the context of its methodology is considered and the key features of human and education resources are discovered. The particular attention is paid to the issue of obsolescence of the staff education resource and the rationale for its diagnostics conducted through the audit of intellectual capital. The necessity of development of the educational resource for the staff of a modern company and the consequent increase of its competitiveness is presented.
\end{abstract}

\section{Introduction}

Under current conditions, one of the key competitive advantages of a company is its qualified personnel. The concept of "lifelong education" sets new objectives for staff training: "... the preparation for mastering the innovative methods of obtaining knowledge, rather than the assimilation of previous approaches, has become global" [1].

Previously the labor market required people to possess a certain set of knowledge and skills, while nowadays, the focus is shifted to the ability to learn, master new fields and types of activities, and possess a certain set of soft-skills, the main value of which is the person's ability to find new solutions of existing production problems. In contrast, traditional education is concentrated on achievement of the practical goals only [1]. The problems of modern education begin with the school system, long before an individual reaches a professional level of education. However, the imperfection of school training affects the further development of a person in adult life. The opinion of Pakhomov N.N. is undoubtedly true. The scientist states that the school "... failed to adequately replace the family, church, social and professional groups. Therefore... trains a person possessing knowledge, but not aware; moralizing, but immoral; educated, but uncultured" [2]. With increasing frequency, the system of vocational training encounters the problem of a low level of development of students in general education subjects and insufficient basic

*Corresponding author: lusis63@mail.ru 
knowledge for the acquisition of professional disciplines or modules. Under such conditions, in secondary vocational as well as higher education institutions, the objective of organizing additional classes or preparatory faculties in order to eliminate gaps in knowledge and further successful assimilation of the educational program becomes relevant.

Nevertheless, in order to attain the objectives stated, the article is focused on the consideration of issues of continuous professional training of adults, since the applied aspect of improving the productivity of work and the company success greatly depends on the performance potential of employees. The development of new industries, technical progress and the consequent emergence of new requirements of personnel that performs various industrial-economic functions dictate the need for continuous education.

The purpose of the article is to reveal the methodologies of continuous professional training and to determine the value of the education resource regarded as a capital asset of a company.

Methodological basis of the research. The idea of continuous education is not considered to be new. Even (Russian) folklore proves the existence of the "continuous education" phenomenon. The following proverbs could serve as an example: "it is never too late to learn", "live and learn", "literacy is not a disease, it doesn't take away years", "literacy education is always useful" etc.

There are several points of view on the origin of the idea of continuous education among the researchers that study the issues of continuous adult education. They are described in the work of E. V. Lopatkina [1]. Thus, the supporters of the ancient origin of the idea under discussion are Darinsky A.V., Hummel H., Yagodin G.A., and others. These scholars believe that "the idea of continuous education has existed for as long as humanity has". The other scientists, such as Kuptsov O.V., Osipov V.G., and others, associate the emergence of this idea with the modern era, which is characterized by the dynamic development of all fields of the national economy and the introduction of new activities. The third point of view, supported by Vladislavlev A.P., Zinchenko G.P., Onushkin V.G., and others, connects the origin of continuous education idea to the age of Enlightenment. Several groups of philosophers, thinkers and scientists of different periods of historical development, whose works involve reflections on continuous education are distinguished (Plato, Aristotle; Voltaire, Goethe, Comenius, Rousseau; Pirogov N.I, Ushinsky K.D., etc.) [1].

The work of Pisarev D.I. "Selected pedagogical essays" - Moscow, 1984 is dedicated to the idea of continuous education. The scholar wrote: "It is important to learn at school, but it is much more important to learn after school, and this second education with its consequences, its impact on a person and society is immeasurably more valuable than the first one" [3].

The development of the idea of continuous education is associated with the humanistic approach, in which the focus is on the person, the individual, the person's desires and aspirations, the wide development of the individual's abilities [1].

The consideration of the genesis of the concept of "continuous education" is of particular interest. The examination could be carried out according to the terms which it was defined by in different historical periods in various countries. The table demonstrates the key concepts and their English-language equivalents that denote the idea of "continuous education". 
Table 1. Terms denoting the development of the idea of "continuous education".

\begin{tabular}{|c|c|}
\hline Продолжающееся образование & Continuing education \\
\hline Пожизненное образование & Lifelong education \\
\hline Перманентное образование & Permanent education \\
\hline Продолженное/непрерывное образование & Continuous education \\
\hline Реккурентное образование & Recurrent education \\
\hline
\end{tabular}

The importance of continuous education is considered by various theories. For instance, the theory of human capital, described in the work of Klyucharev G.A. "Continuous education is a stimulus for person's development and a factor of socio-economic inequality" suggests that "education is not a product of final consumption, but serves as a means of further production of added value, being an important factor in national and global macroeconomic growth, as well as a means of ensuring income growth for individuals and companies" [4].

The theory of human capital was developed in the 1960s. The very concept of "human capital", regarded as a set of knowledge, skills, and abilities, was proposed in the works of American economists Schultz and Becker G. by analogy with the traditional concepts of physical and financial capital. In the monograph of Klyucharev G.A., Didenko D.V. and Latov $\mathrm{Yu}$.V. the approach of American economists is interpreted as follows: "putting these concepts in one row, the economists stressed that the knowledge that a person possesses becomes the main source of the person's well-being in the modern world, and the possession of knowledge is in many aspects more important than the possession of property (real estate, shares, money)" [4].

\section{Analysis}

The fundamental feature of the human resource and its difference from other types of resources - material, financial, information and others - should be noted. First, the human resource is not consumed as it is used in proportion to the quantity of newly produced goods or performed services. That is, the company's personnel, which is a work force and collectively represents the company's human resource, while performing production and economic functions, does not lose its potential, but on the contrary has the ability to accumulate it, which is manifested in the improvement of skills and acquisition of new knowledge by staff, that is, in fact, the growth of professional qualifications and experience accumulation. In addition, as a distinctive feature of human resource, it is worth paying attention to such an aspect as the conscious choice of professional activity. Since a person chooses the type of activity consciously, the motives of this action and the degree of satisfaction from work which affects the success (or failure) of personal development within the chosen profession are crucially important. The feeling of success in a business career is a strong motivator for the further development of personnel in the profession.

It could be stated that human resource is accompanied by the education resource of a company, which is displayed in the knowledge, skills, and level of competence of its personnel. At this point, it should be noted that the education resource, like any other capital asset of a company, is subject to obsolescence (depreciation). This is not characterized by a loss of resource while using, but is related to the rapidly changing environment and the ability of employees to broaden their knowledge due to the new requirements and the opportunities to meet them.

The deprecation of the education resource could be both physical and moral. Physical deprecation could be manifested in the loss of information due to the fact that a person tends to forget what he/she does not use constantly and does not update his/her knowledge periodically. It might also occur due to the health condition, age-related changes, when a person's perception is blunted, as well as due to the possible dementia and the abrupt 
decline of the analytical abilities. An individual's working practice is not limited to reaching retirement age, however, various types of activities are associated with health restraints which is primarily caused by the need to meet certain parameters for the effective performance of job functions (for instance, jobs that are related to the movement of vehicles or traffic management involve testing not only for knowledge, but also for reaction speed, attention, memory and the ability to make decisions quickly). Moral deprecation of the education resource is associated with a decline of the applicability and demand for knowledge [4], that is, it could turn out that there is a specialist prepared for a certain field of activity, but his/her knowledge is outdated and is not applicable to any sphere of the work. These individuals are presented with retraining or advanced training programs in order to maintain their competitive advantage in the job market and keep their jobs.

The research related to the concept of "half-life competence period", which implies that after a certain period of time, approximately half of the knowledge that a person has acquired during the training becomes outdated, is of great interest. The approximate halflife competence period might be 10,5 or even less years, depending on the field of activity. Otherwise speaking, this is a process of devaluation of previously acquired knowledge [5].

It should be noted that the objective to identify the degree of deprecation of education resource is set not only for the employees, but also for the management of the company where their workforce is applied. The company should possess a knowledge base that would include a description of the personnel's knowledge component (which could be identified with the application of business assessment methods), as well as a description of the manifestations of staff's work performance that exceeds the normative values, rather than formal information on a certain level of education of staff. Furthermore, in such knowledge bases, it is reasonable to accumulate information about the additional opportunities for employees which have not yet been displayed in their practice nor related to job positions. This information would be useful for creating a candidates pool for management and senior positions, as well as for resolving issues related to staff placement and improving in-house mobility through a staff rotation mechanism.

Moreover, the formation of the education resource of a company is associated with the issues of work organization, namely, the manifestation of such an element as the division of work and cooperation. This concerns the fact that knowledge is reinforced in the mind when it is regularly used in practice. Even if the employee initially possessed knowledge in a certain professional field when commencing employment, but it was not applied for a long time, due to an excessively deep division of labor and heavy load involving homogeneous functions during the working day, this knowledge might be forgotten either completely or partially. In this case, a decline in the education resource of the company could be observed. In such situations, the guilty party is not only the employee (who, presumably, has a low motivation to maintain and increase the professional knowledge and skills), but also the company where he/she is employed, since the known mechanisms for staff development, that do not imply the day release or additional expenses, were not applied. One of these mechanisms is personnel's rotation which implies that employees move through positions or workplaces within one or associated professional departments, master related work functions, and apply the existing knowledge and acquire the new one. Thus, the company improves its education resource and gets a staff that is able to learn, dynamically develop, and not stagnate.

\section{Discussion}

Currently, the replacement of the theory of human capital with the emergence of a new theory or a concept of human development is discussed in the scientific literature [6, 7]. This concept puts an increasing emphasis on knowledge which has become the main 
resource and determines the skills and productivity of an employee in the post-industrial economy. Knowledge is of great importance for maintaining the competitiveness of the company's human resource and is a subject to management.

In order to effectively manage knowledge and, as a result, the education resource, it is necessary to regularly diagnose the company's intellectual capital, and its key component human capital, in particular. Such work is possible within the framework of an external or internal audit of intellectual capital, in which one of the objects of diagnostics would be the education resource.

At the present time, in the scientific and industrial environment, there is no consensus on the subject area of intellectual capital audit and the existence of the established procedure for its implementation. Traditionally, diagnostics are performed based on such an indicator as the number (or percentage) of people with a certain level of education. However, even this simplified approach might have its own variations and details diversity of the verification process. For instance, in certain cases, it is necessary to collect and process information about the education of personnel by groups of training areas or professions: people with a higher education - in humanities, management, pedagogy, as well as technical, medical, military education, etc. The same division could be conducted for people with secondary vocational education. Thus, it is possible to conduct diagnostics according to the education level of personnel of different categories, different departments, different professions, etc., and to receive a more complete information about the qualifications of staff for further analysis as well as for making various management decisions related to both the company's reorganization and its development.

In the process of evaluation of the education resource, it is possible to get information from documented sources - diplomas, certificates, licenses, etc. For instance, adding documents that confirm the employee's qualifications to the company's database creates an information resource that reflects both the education and the qualification level of the staff. It should be noted that traditionally, human resources request for employees to provide the education and qualification documents that correspond to the position they hold, however, most commonly, the human potential significantly exceeds what is used in the performance of specific job functions. Therefore, it is reasonable to enter all the information about the knowledge that the staff possesses into the database (or knowledge base). However, the problem of hiding information about the completion of education or the possession of certain competences by employees themselves could be encountered. It might be caused by different factors: disillusionment with the previous work, former profession, unwillingness to have additional work or instructions from the manager, which could be a consequence in case the manager finds out about the employee's existing competencies, modesty of a person, and many other factors. Therefore, from the perspective of personnel management, in order to form the most complete knowledge base, it is necessary to find methods of staff encouragement to disclose their competences and to further develop them for effective work performance. One of the mechanisms for disclosure of such information by employees is the portfolio, which is currently becoming more popular both in the educational and industrial spheres. Most commonly, employees, trying to make their portfolio richer and more interesting, and expecting various types of rewards for their achievements, include both major and additional information that is not related to work activities.

In addition to the formal assessment of the intellectual capital, and the education resource of personnel, in particular, there are many methods for evaluation of personal characteristics of the staff members that affect their career success. Within the framework of an audit of intellectual capital, it is reasonable to conduct psychodiagnostics of personnel with a preliminary determination of the trend of the study under discussion [8]. The definition of the research purpose is of key importance, since every individual has a wide 
range of abilities and they could be almost endlessly studied; as frequently, a person is not aware of all his/her psychoemotional and psychophysiological features. Therefore, the first stage of this audit should be the definition of the research purpose. For instance, in case there is a need to select personnel in the candidates pool for management positions, it is necessary to evaluate the candidate according to the leadership skills, public speaking skills, the ability to resolve conflict situations, to interact with the staff, etc. Alternatively, in case the objective is to place the staff and to select an employee, for example, for the analytics department, the evaluation of the employee's analytical abilities, critical thinking, attentiveness, etc., is needed. All the data identified through the application of the methods of psycho-diagnostics must be registered in the database of the company. However, it should be noted that such research and further processing and use of the received information is possible only with the consent of the staff. On the one hand, the data discovered by psychodiagnostics are not regarded as the education resource of the staff in its proper sense, but are rather of indirect nature, which undoubtedly affects the performance of certain work functions. On the other hand, these personality traits are an important component of the career success.

\section{Conclusions}

Thus, it can be concluded that modern companies in order to improve their competitiveness should timely diagnose and accumulate the education resource of the personnel, which is one of the key assets of a company, as well as take steps to reduce the deprecation of the education resource through the application of the system of continuous vocational education for their employees.

\section{References}

1. E.V. Lopatkina, Materialy Vserossiyskoy nauchno-prakticheskoy konferentsii "Nepreryvnoye obrazovaniye - strategiya zhizni sovremennogo cheloveka" (Vladimir, 2014)

2. N.N. Pakhomov, Kul'tura, obrazovaniye, razvitiye individa (M., AN SSSR, 1990)

3. E. Ganebnykh, I. Altsybeeva, E. Gurova, SHS Web of Conferences 35, 01029 (2017)

4. G.A. Klyucharev, D.V. Didenko, Yu.V. Latov, Nepreryvnoye obrazovaniye - stimul chelovecheskogo razvitiya i faktor sotsial'no-ekonomicheskogo neravenstva (M., 2014)

5. A. Mottaeva, A. Ivashchenko, A. Ryattel, E3S Web of Conferences 164, 10038 (2020) https://doi.org/10.1051/e3sconf /202016410038

6. E. Vasilyeva, A. Mottaeva, E3S Web of Conferences 91, 08051 (2019) doi.org/10.1051/e3sconf /20199108051

7. M. ul. Haq, Reflections of Human Development (N.Y. Oxford University Press, 1995)

8. A.L. Zhukov, Audit chelovecheskikh resursov organizatsii: uchebnoye posobiye (M., MIK, 2010) 